\title{
6. THE 1990-91 GULF WAR: OIL FIRES, ECOLOGICAL CATASTROPHE, AND A SECOND RUPTURE
}

Kuwait maintained its position as the role model of the oil welfare state until that moment when the 1990-91 Gulf War made the firm belief in petroleum as harbinger of a prosperous future vanish into thin air. Leading up to it, the 1980 s were a turbulent decade: in 1982, the country experienced the crash of its unofficial stock market Souq al-Manakh, subsequently a rapid decline of petro-welfare that had been created with the "Kuwaiti model," and the temporary suspension of the constitution and the National Assembly in 1986. In August 1990, the Iraqi army under Saddam Hussein invaded Kuwait and annexed the city-state. Especially for Kuwaitis, but by default for the Gulf region at large, the resulting Gulf War and the images of burning oil wells and massive oil spills unfolded a destructive side of petroleum on a scale hitherto unknown that sedimented in the collective memory of the region.

The Gulf War, which was effectively a war about petroleum, played out in a calamitous stroke against Kuwait's political, social, and financial viability as well as in a devastating ecological catastrophe caused by military warfare, oil fires, and oil spills. Consequently, a shift in the ways in which petroleum was seen and valued happened. Following the oil industrialization in the mid-twentieth century, petroleum had predominantly represented political stability, prosperity, and sociocultural modernization on the Arabian side of the Gulf in accordance with the interests of various stakeholders as the discussion in the previous chapters has shown. Now, around forty years later, petroleum had triggered a hitherto unimaginable nightmare that left Kuwait and the Gulf in limbo. Kuwait's personal "oil curse" became the Gulf War, from the Iraqi invasion, Operation Desert Storm, to the fight against oil spills and fires in the months after the war had ended. Therefore, as a historic case study, Kuwait and its twentieth-century relationship with oil not only represent the extraordinary and sudden abundance of petro-pleasures, but also the confrontation with petro-modernity's worst nightmares, for which the history of petroleum in Kuwait puts the whole spectrum of iridescence on display. Looking back, Kuwait's "golden era" came to an end with the Iraqi invasion and the Gulf War. 


\section{A War About Petroleum}

On August 2, 1990, the Iraqi army invaded Kuwait crossing their shared northern border and occupied Kuwait City. Iraq had just emerged defeated from the draining Iran-Iraq War (1980-88) and the military maneuver hit Kuwait rather unprepared. ${ }^{1}$ Yet, Iraqi threats to Kuwait's sovereignty were nothing new. Already in 1961 shortly after Kuwait's independence from Britain, Iraq had questioned its neighbor's political status and claimed to incorporate Kuwait's territory into its realms as a "19th province." ${ }^{2}$ These were not just empty words, as the newly-independent Iraqi state under Abd al-Karim Qasim mobilized its forces along the shared Kuwaiti-Iraqi border to underline its claims. At the time, British troops were moved to Kuwait and were later superseded by troops of the United Arab Republic, Jordan, Saudi Arabia, Sudan, and Tunis to prevent a military conflict. Although the insecurity that a bigger (neighboring) country would invade the city-state had remained ever since, the threatening feeling had been more or less successfully suppressed during the following peaceful and prosperous decades. ${ }^{3}$ Yet, Iraq's motivation to claim the rich oil reserves and the sophisticated infrastructure that Kuwait had built and showcased in a myriad of circulating images resurfaced abruptly in the early nineties. ${ }^{4}$

What unfolded over the following seven months was a political, social, ecological, and economic catastrophe with petroleum as the decisive factor in it. Prior to the invasion, Kuwait's oil industry had produced around 2 million barrels of crude oil per day and refined around 750,000 barrels daily in high-tech refineries. ${ }^{5}$ By the time the Iraqi army had left, according to the KOC, at least 613 oil wells were ignited, an additional 76 wells

\footnotetext{
1 Although the invasion of the Iraqi army surprised Kuwait's citizens and residents overnight, it did not come totally out of the blue in the summer of 1990. The invasion preceded debates among Iraq, Kuwait, and other OPEC members regarding the oil price and the production volume. Iraq had argued in favor of a substantial oil price raise and had accused Kuwait of putting too much oil on the market. Negotiations between Iraq and Kuwait held in Jeddah on August 1 failed. At the time, Iraqi troops were already stationed along Kuwait's northern border. Shortly after the Iraqi army had occupied Kuwait, the United Nations ratified several resolutions that Iraq should retreat peacefully, arguing that its claims were unjustified and imposed various international sanctions against Iraq. Many countries decided on oil embargos against Kuwaiti and Iraqi oil. Iraq's oil pipelines, such as the al-Muajjiz Pipeline across Saudi Arabia and the Kirkuk-Ceyhan Pipeline to the Mediterranean crossing Turkey, were consequently closed, while imports into Iraq and Kuwait were sanctioned and aviation was blocked.

${ }^{2}$ For a detailed discussion, see Miriam Joyce, Kuwait, 1945-1996: An Anglo-American Perspective (London: Frank Cass, 1998). For contemporary newspaper reports, see “The News in Pictures," The Sphere July 8, 1961, 43; “The Allure of Oil and the Threat to Independence: Tension in Kuwait," Illustrated London News, July 8, 1961, 40-41.

${ }^{3}$ Kuwaiti historian Hassan Ali al-Ebraheem described Kuwait's feeling of geopolitical insecurity as that of a "small state living in a bad neighborhood." Quoted after Mary A. Tétreault, "Kuwait: The Morning After," Current History 91, no. 561 (1992): 6.

4 Ibid.

5 Ibid.
} 
were gushing only, and 99 were damaged. ${ }^{6}$ Considering that Kuwait had 1,135 operating oil wells prior to the invasion, this was a substantial blow to its oil industry and thus its national economy. ${ }^{7}$ Tellingly, never before in the history of Kuwait or the Gulf had petroleum as raw material become so visible and visual as when the oil fields started burning and massive oil spills stained the desert, coastlines, and the Gulf waters. Kuwait's petro-modernity culminated in this dramatic upsurge that openly revealed not only what greed for oil and petro-capitalism could do but petroleum's toxicity as it destroyed Kuwait's and the Gulf's flora and fauna and caused heavy air pollution that people were immediately affected by.

During and immediately after the Gulf War, scientists were afraid that the oil spills and oil fires in Kuwait and Saudi Arabia (where most of the sea-carried oil arrived) would cause globally devastating scenarios such as "a global climate chill, intense acid rain, or a failure of the monsoons in Asia." It quickly amounted to a potentially global threat revealing the strategic importance of Kuwaiti oil to the global economy as well as the unknown hazardous potential of the gigantic amounts of oil that escaped out into the open; something that Gulf oil states and oil companies operating there had tried to prevent all along. Moreover, for people living in Kuwait, citizens and residents alike, petroleum, prior to August 1990, had come to signify Kuwait's national identity and its prosperous future perspective (as wealthy, sovereign state). The Iraqi invasion not only destroyed the material and economic base, but also hollowed out these components of identity. Overall, the Gulf War disclosed the fragility of the Kuwaiti oil welfare state and of a global economy that essentially depended on oil and was willing to wage war for it.

Early in the Gulf War, Saddam Hussein announced that petroleum would be used as a weapon of war and Kuwait's oil reserves would be destroyed. Given Kuwaiti oil's strategic importance but also the alleged fear that Iraq would build an atomic bomb or use chemical weapons, the United States, together with Canada, Great Britain, and France, initiated the Operation Desert Shield, gathering air and ground forces in the region, especially in Saudi Arabia, in preparation of a strike against the occupying Iraqi forces in Kuwait. ${ }^{9}$ Mary Ann Tétreault has highlighted that Kuwait's government-in-exile paid substantial amounts to the US and other partners in the allied coalition for the invasion. ${ }^{10}$ After Saddam Hussein ignored the final ultimatum set by the United Nations to leave Kuwait by January 15,

\footnotetext{
${ }^{6}$ Muhammad Sadiq and John C. McCain, The Gulf War Aftermath: An Environmental Tragedy, Environment \& Assessment 4 (Dordrecht: Kluwer Academic, 1993), 59. Overall, estimations vary greatly, see the tabular overview in Sadiq and McCain, The Gulf War Aftermath, 67, table 3.1.

7 Sadiq and McCain, The Gulf War Aftermath, 68, table 3.2. Tétreault, however, mentions 1,330 active oil wells, Tétreault, "Kuwait," 6.

${ }^{8}$ Faye Flam, “A Brighter Forecast from Kuwait," Science 253, no. 5015 (1991): 28.

${ }^{9}$ However, no evidence for chemical weapons nor an immediate nuclear threat could be found, Marie Gottschalk, "Operation Desert Cloud: The Media and the Gulf War," World Policy Journal 9, no. 3 (1992): $452,463$.

10 Tétreault, “Kuwait," 9.
} 
1991, the coalition started its aerial attack on January 16. In what is known as Operation Desert Storm, allied ground and aerial attacks on the Iraqi army continued over the next forty-three days. On February 28, Kuwait was liberated, but many human lives had been lost and much petroleum spilled.

It was not only a war about petroleum, it became a war with petroleum; not only a fossil-fueled war, but a crude war. The Iraqi army under Saddam Hussein occupied and annexed the Gulf monarchy; it then looted the country, especially its oil fields. During December 1990 to late February 1991, Iraqi troops set over 600 oil wells on fire and damaged oil terminals, pipelines, refineries, and berthing tankers. Yet, it is now believed that US-led bombing also caused severe damage to the oil facilities and contributed to the known oil spills. ${ }^{11}$ As a result of the escaping crude, as one study published in the journal Science noted, "close to the fires the smoke rained oil drops... . This oil, together with soot fallout, coated large areas of the desert with a black, tar-like covering." ${ }^{12}$ In addition, as the study reported, "oil spewing out from uncapped wells formed large pools of oil on the desert, some of which were alight." ${ }^{13}$ The oil that emerged from the oil wells now built its own tarred roads in the desert and constructed its own pools, not swimming pools, but pools filled with tar. ${ }^{14}$ Once the Iraqi army had withdrawn, Kuwait became the scene of an international battle against the burning oil wells and the seeping of oil into the Persian Gulf, until, on November 6, 1991, the last oil well fire was finally extinguished. In this short period between August 1990 and then, some of the most iridescent images of oil emerged that are emblematic of the ambivalence of petro-modernity overall.

\section{The Ecological Catastrophe as an Aerial View}

An aerial photograph taken by the National Aeronautics and Space Administration (NASA) from their space shuttle Atlantis on April 7, 1991, shows the oil well fires and the smoke plumes north and south of Kuwait City (fig. 6.1). ${ }^{15}$ From an altitude of 457 kilometers, the characteristic spit of Kuwait Bay with its densely built-up urban area contrasts with the hinterland and the Gulf. Several hundred burning oil wells cast their lengthy pitch-black smoke plumes that drift from north to south over the region,

${ }^{11}$ Gottschalk, "Operation Desert Cloud," 453.

12 Peter V. Hobbs and Lawrence F. Radke, "Airborne Studies of the Smoke From the Kuwait Oil Fires," Science 256, no. 5059 (1992): 987. See also Sadiq and McCain, The Gulf War Aftermath.

${ }^{13}$ Hobbs and Radke, "Airborne Studies of the Smoke From the Kuwait Oil Fires," 987.

${ }_{14}$ In the early 2000s, a project was proposed to pave "roughly 5,000 kilometers worth of roads" using high-petroleum concentrations in the sand that remained from the war. The reporting journalist commented sarcastically, "When life gives you asphalt, make a highway." See Ben Shouse, "Kuwait Unveils Plan to Treat Festering Desert Wound," Science 293, no. 5534 (2001): 1410.

15 "Smoke from a Distant Fire," Nasa Earth Observatory, July 8, 2011, accessed January 18, 2021, https:// earthobservatory.nasa.gov/features/ShuttleRetrospective/page8.php. 


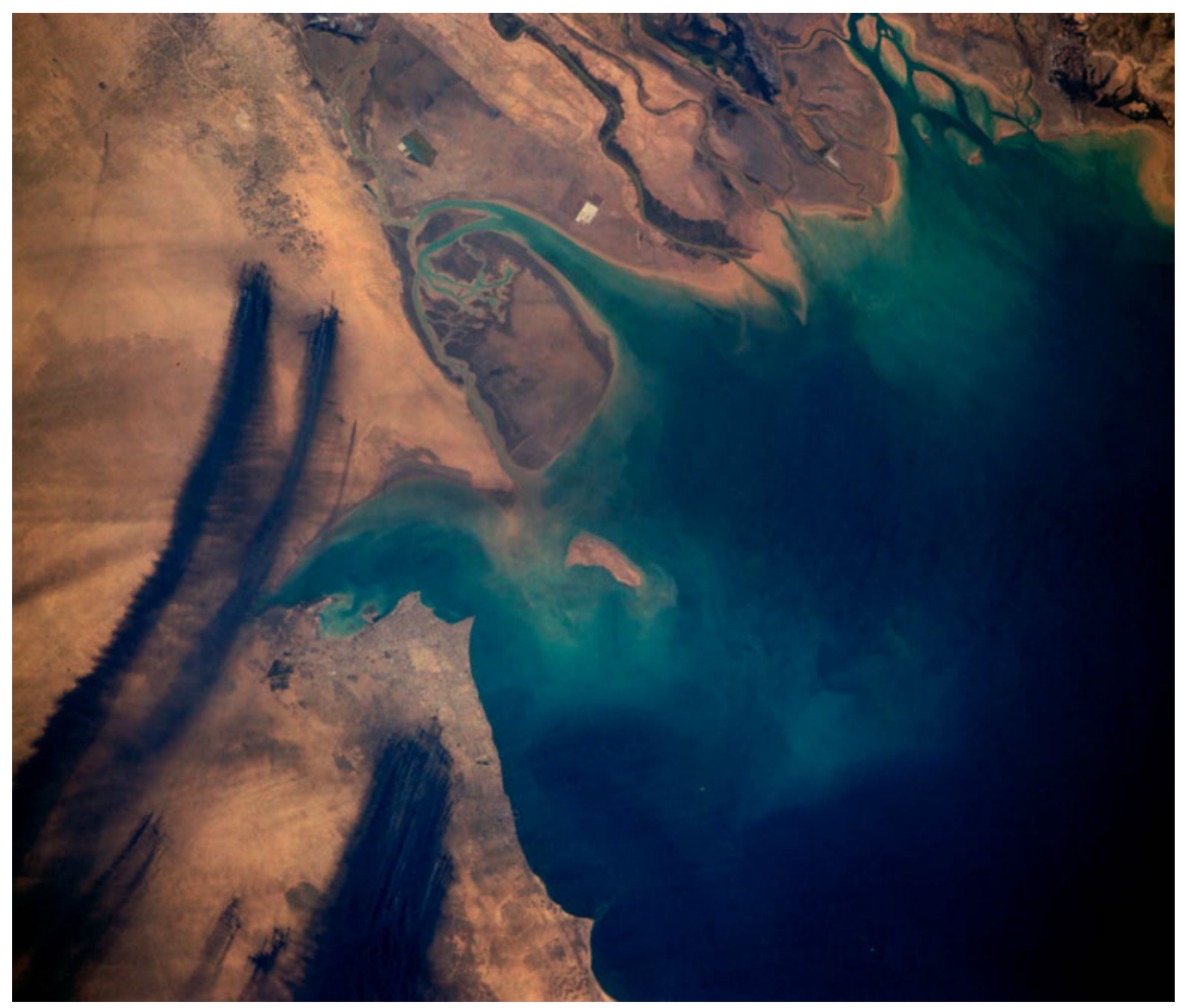

6.1 Aerial photograph taken by the NASA from the space shuttle Atlantis on April 7, 1991, that shows the oil well fires and the smoke plumes on Kuwaiti territory.

enveloping it for hundreds of kilometers in darkness. By the late 1980s, lifestyles across the globe had become reliant on the burning of fossil fuels, but in 1991, the downside of oil cultures materialized as geographically condensed form in Kuwait, as the earth was bleeding black tears across the sand and sea for hundreds of kilometers. Therefore, the aerial images of this oil catastrophe encapsulated the age of fossil energy and the high costs of its anthropogenic deployment.

Aerial imagery provided by agencies like NASA, the Système Probatoire d'Observation de la Terre (SPOT), and LANDSAT Thematic Mapper (LANDSAT TM), was crucial in determining whether and where oil wells were burning as well as the quantity of oil fired up at each side. It has been estimated that the approximate 6 million barrels which burned per day would have fueled 7,312,500 tanks of a regular car or a jet for 193 trips around 
the globe. ${ }^{16}$ In addition, once the war had ceased, various scientific initiatives flew aerial surveys to examine the smoke dispersion and to describe the morphology of fire flames and smoke plumes. ${ }^{17}$ Like crude's iridescence and pearls' luster and shapes, the flames and the smoke emitted by the oil fires were not only of different shapes, but they also displayed a "color" spectrum, so to speak, varying from "gray-white to dense dark in color," depending on the exact chemical characteristics of the burning matter. ${ }^{18}$

Shortly thereafter, cultural analyst Andrew Ross argued that "if the oil slick became the leading ecological actor during the war itself, the spectacle of the burning Kuwaiti oil wells played the starring role in the media war's denouement... . The oil slick and the burning wells were the only images of ecological spoliation the public did get to see, and the ones that the public remembers." ${ }^{19}$ These images also came to stand in place of the human beings who died and the several hundred prisoners of war on both sides, many of which never returned. Ross added that the circulating aerial images of the ecological catastrophe helped to distract from the military complex (allied and Iraqi) as probably the biggest pollutant in the conflict. ${ }^{20}$ The disembodied aerial view as cast from an unmanned satellite or a detached space shuttle again unfolded its play of miniaturization and sublime minimization of the violent social actions taking place on the ground.

In light of the decades-old debate about the peak of fossil deposits and their finiteness, the Kuwaiti oil fires and oil spills sarcastically testified to the substantial availability of the fossil raw material in the Gulf region. The question that oil companies, nation-states, scientists, citizens, activists, and journalists have always asked and have since continued to ask-how long will oil last? —-was answered in smoke and fire, loud and clear: for a long time. And for once, this response was met with ambivalence, at least as long as the region suffered under the smoke, the fires, and the loss of its resources. The ecological catastrophe as it spilled out on site and emerged in imagery did not lead to a serious consideration of stopping the oil production in Kuwait or the region. Rather, the visual representations of oil spills played favorably into the hands of the controlled corporate exploitation of petroleum, given that the KOC represented a (also visual) history of uninterrupted, efficient oil production with hardly any ecological calamities until 1990. Even the nationalization of the industry in 1976 had been a peaceful takeover. It is therefore not surprising that there was an overall agreement on reopening industrial production in Kuwait once the oil spills were brought under control.

\footnotetext{
${ }^{16}$ Christ Paine and John Quigley, “Gulf War Oil Disaster," Counterspill, accessed February 5, 2021, https:// www.counterspill.org/disaster/gulf-war-oil-disaster\#timeline.

${ }_{17}$ Sadiq and McCain, The Gulf War Aftermath, 76-80, 86-90.

18 Ibid., 60.

19 Andrew Ross, “The Ecology of Images," in Visual Culture: Images and Interpretations, ed. Norman Bryson, Michael A. Holly, and Keith P. F. Moxey (Hanover: Wesleyan University Press, 1994), 327.

${ }^{20}$ Ibid., 327-28.
} 
With the Gulf War, Kuwait's existence was revealed to be tied to petroleum for good. Petroleum had stimulated both Kuwait's stability during the "golden era" and the country's fragility during the 1990-91 invasion. Until today, the latter marks a historic caesura in Kuwait's history, a second rupture or transformation causing a new nomenclature of "pre-" and "post-war." Yet, how Kuwaiti citizens and residents experienced and came to view the war differs greatly. Given that the invasion happened during the hot summer months, many Kuwaitis were abroad, on holidays, business trips, or in their second homes elsewhere. Only about one third of the population experienced the invasion as "insiders" in the country itself, while the "outsiders" watched it from afar on television together with the rest of the world. ${ }^{21}$ Even people who remained inside Kuwait often watched the warfare unfold on their TV sets, and so the Iraqi invasion became a TV experience and a mass-media spectacle for many, starring petroleum as an element with major screen time. Political scientist Marie Gottschalk and others have concluded that the Western and especially US media coverage of the Gulf War was heavily biased. ${ }^{22}$ The sophisticated technology of media coverage "was employed primarily to transport the viewer to the big event, not to increase the viewer's understanding of the big picture." 23 Often called a "video-game war" due to its precision bombing and night-vision equipment that felt "cinematic and often sensational" underlined with "pounding new theme music," it comes hardly as a surprise that the Gulf War has been given a firm presence in video games such as Battlefield 3 (2011) and Call of Duty: Modern Warfare (2019). ${ }^{24}$

\section{The Gulf War and Visual Culture}

The Gulf War has triggered various forms of documentary and artistic engagement with the events ever since. Providing a detailed analysis of the visual culture and subsequent artistic examination of the Gulf War would exceed the scope of this book, although its art-historical analysis would be an important undertaking especially as the historic documentation, scientific investigation, and artistic inquiry of the Gulf War appear very heterogenous with multiple, contradicting narratives and perspectives. To provide a preliminary idea of the range that spans the Gulf War's visual culture, I point to some aspects that would be worthy of further research.

\footnotetext{
${ }^{21}$ Philip Shenon, "A New Divide for Kuwaitis: Who Stayed and Who Fled," The New York Times, March 12, 1991, 13, accessed January 18, 2021, https://www.nytimes.com/1991/03/12/world/after-the-war-kuwaitipolitics-a-new-divide-for-kuwaitis-who-stayed-and-who-fled.html.

${ }^{22}$ Gottschalk, "Operation Desert Cloud”; Stewart Purvis, “The Media and the Gulf War," RSA Journal 139, no. 5423 (1991).

${ }^{23}$ Gottschalk, “Operation Desert Cloud," 472.

${ }^{24}$ Ken Burns, “The Painful, Essential Images of War," The New York Times, January 27, 1991, accessed February 5, 2021, https://www.nytimes.com/1991/01/27/arts/the-painful-essential-images-of-war.html.
} 


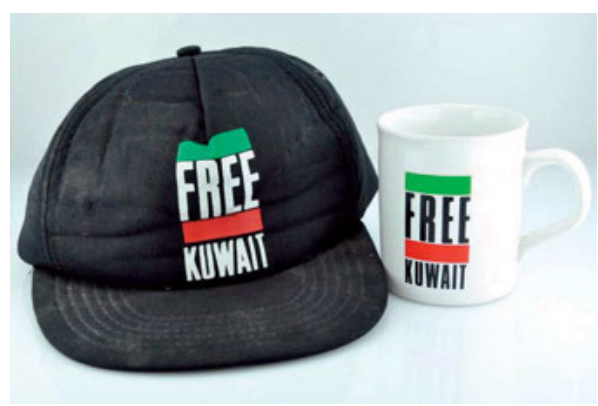

6.2 Hat and mug with the Free Kuwait logo which had been designed by Michael Lorrigan, Sam Bassan, and Ali Al-Mulaifi. Photograph taken by Adel Al-Yousifi, 2012.

Almost immediately after the country's occupation, Kuwaiti citizens and government officials, who were exiled abroad, formed the Free Kuwait Campaign together with sympathizing foreigners that became crucial in advocating for Kuwait's liberation and for the reinstation of the Kuwaiti government. The "Free Kuwait" logo, which consists of a horizontal green stripe, the capitalized writing "FREE", a red horizontal strip and the capitalized writing "KUWAIT" stacked below one another-in reference to the Kuwaiti flag-became crucial in promoting the movement widely and visibly (fig. 6.2). The campaign materialized and mobilized with the help of a broad variety of merchandise articles, such as caps, pins, and T-shirts, with the eye-catching logo.

A member of Free Kuwait in Britain, the Kuwaiti photographer Adel Al-Yousifi returned from London to Kuwait once air flights were permitted again and subsequently documented the immediate aftermath of the war in over 15,000 photographs covering not only Kuwait City but also the hinterland and coastal areas. Today, Al-Yousifi has

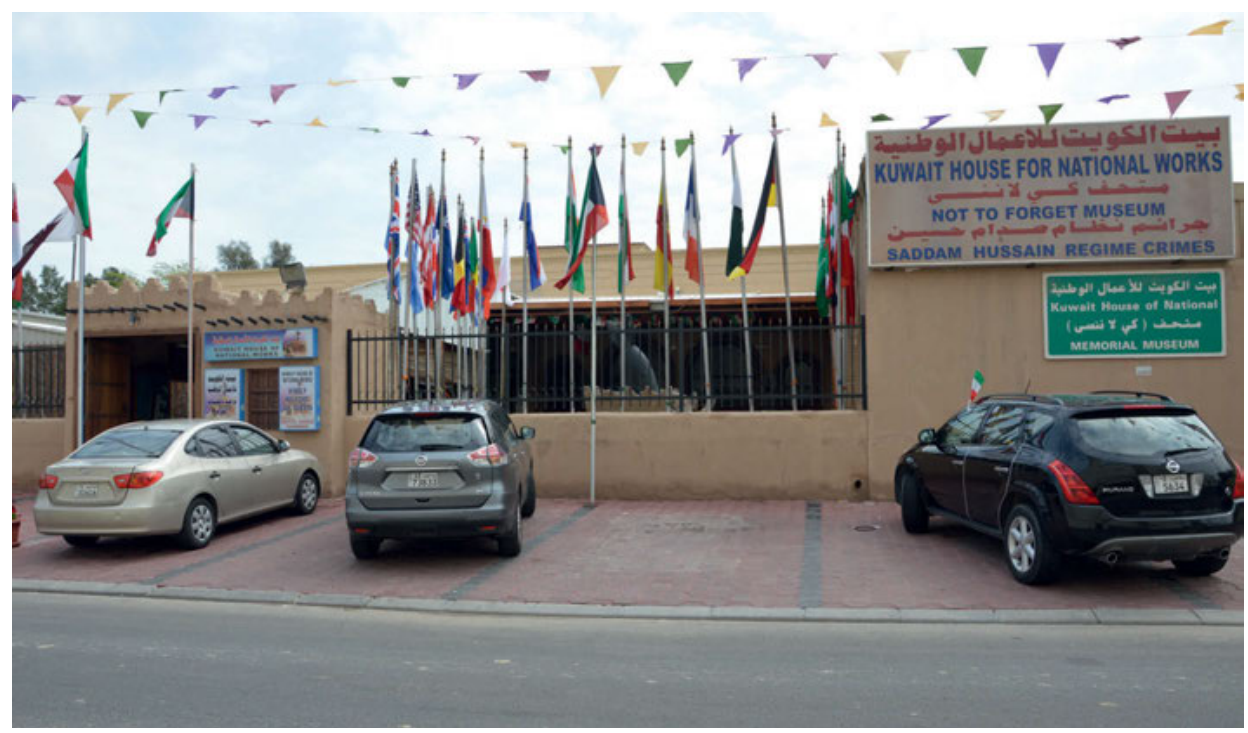

6.3 The entrance of the Kuwait House for National Works, Kuwait City. Photograph taken in February 2016. 


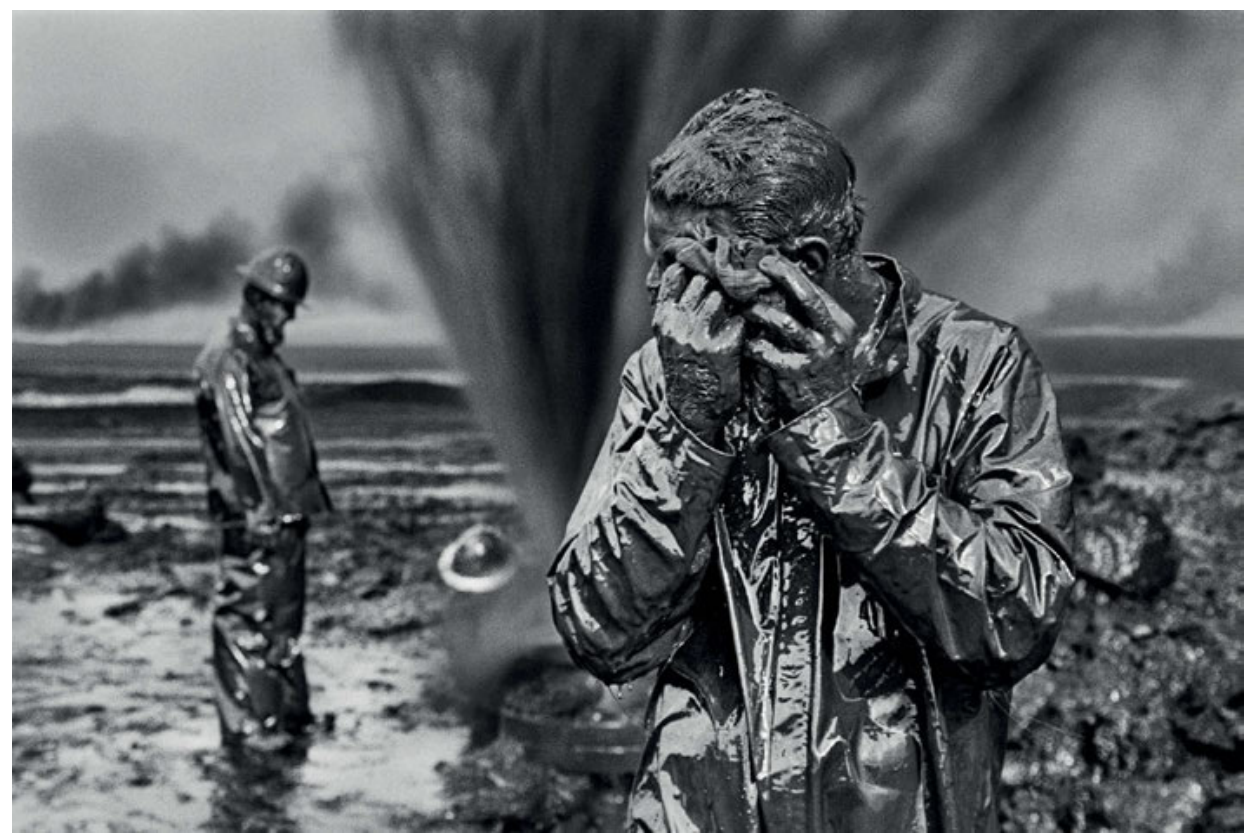

6.4 Sebastião Salgado, Desert Hell, Kuwait, 1991. Gelatin silver print.

published his photographs and his point-of-view online with an extensive website. ${ }^{25}$ Moreover, his photographs became publicly accessible as part of the memorial museum bayt al-Kuwayt li-l'amāl al-wațaniyya (The Kuwait House for National Works), also called the "Not to forget Museum Saddam Hussain Regime Crimes," which is a private initiative. The museum, located in a converted warehouse, thematizes the Iraqi invasion in form of illuminated dioramas and photographic displays of the warfare and damage done to Kuwait and its society (fig. 6.3). ${ }^{26}$

Another extensive photographic corpus, which has already received international attention, was created by Brazilian photojournalist Sebastião Salgado ( ${ }^{\star} 1944$, Aimorés, Brazil). ${ }^{27}$ Salgado visited Kuwait throughout the month of April 1991 to photograph the joint efforts of Kuwaiti and international teams to extinguish the burning oil wells for a

\footnotetext{
${ }_{25}$ Adel Al-Yousifi, “Kuwait Invasion: The Evidence," Evidence, accessed February 5, 2021, http://www.evidence.org.kw.

${ }^{26}$ Yasser Mahgoub briefly mentions the museum, but a substantial analysis is yet missing. See Yasser Mahgoub, "The Impact of the War on the Architecture of Kuwait," International Journal of Architectural Research 2, no. 1 (2008): 239.

${ }^{27}$ Salgado first started out as an economist, shifting to photography in the early 1970 s. He became an associate member of Magnum Photos in 1981 and a full member in 1984.
} 
New York Times reportage that appeared in June. ${ }^{28}$ The stylized portraits of fire fighters drenched in metallic shimmering mud, the oil slick, are emblematic (fig. 6.4). The iridescent oil slick, which also coated every rift of the environment, in combination with the sheer endless variations of dramatic shapes of oil fires, smoke, and clouds made the catastrophe appear both haptic and sublime. Twenty-five years later, in 2016, Salgado and his wife Lélia Wanick Salgado published the photobook Kuwait: A Desert on Fire that contains a large number of partly unpublished photographs taken in 1991. Asked about the reasons for publishing the shots so many years later, Salgado explained: "I felt the images had a timeless quality; they were taken in 1991, but they could be taken today or tomorrow if a similar disaster occurred." ${ }^{29}$ Thus, in Salgado's view, the ecological catastrophe that affected Kuwait and the Arabian Peninsula stands in pars pro toto for oil disasters around the world that have since regularly occurred and will most likely continue to happen in the future.

Recently, renewed interest in artworks that thematize the Gulf War was demonstrated. MoMA PS1 showed the exhibition Theater of Operations: The Gulf Wars 1991-2011 from November 2019 to March 2020 in New York. ${ }^{30}$ Linking the Gulf War with the Iraq War that started in 2003 and the since then ongoing military conflict, the curators Peter Eleey and Ruba Katrib brought together "a multigenerational group of Iraqi and Kuwaiti artists, and some of Iraqi descent, who were working contemporaneously in different regions and under differing circumstances" in conjunction with Western artists, mostly from the US. ${ }^{31}$ The show deliberately discusses the US involvement in these wars, investigating the relationship with Iraq in particular. Still, a substantial number of artworks thematize the invasion in Kuwait and the 1991 Gulf War, such as several paintings and drawings by Thuraya Al-Baqsami, the War Diaries of Dia al-Azzawi, Susan Crile's Field of Fire, video works by Monira Al Qadiri and Alia Farid, as well as photographic works by Tarek AlGhoussein and Jean-Luc Moulène. Taken together, they provide for divergent experiences, perspectives, and subjectivities through which to examine the atrocities as well as the role oil has played in the conflict.

\footnotetext{
${ }^{28}$ Wald wrote that "Salgado shoots an average of 10 to 12 rolls a day. In the Kuwaiti oilfields, he shot 200 rolls, or a little more than 7,000 pictures, of which he printed an average of six from each roll, in small work prints. From these he selected 47 to send to this magazine. (Usually, photographers send either all their film of a shoot to their editors or their selection of hundreds of prints)." Matthew L. Wald, "Sebastiao Salgado: The Eye of The Photojournalist," The New York Times, June 9, 1991, 72, accessed February 5, 2021, https://www. nytimes.com/1991/06/09/magazine/sebastiao-salgado-the-eye-of-the-photojournalist.html.

${ }^{29}$ Sebastião Salgado and Lélia Wanick Salgado, Kuwait: A Desert on Fire (Cologne: Taschen, 2016), 15.

${ }^{30}$ Peter Eleey and Ruba Katrib, eds., Theater of Operations: The Gulf Wars 1991-2011 (New York: MoMA PS1, 2019); Exhibition catalog published in conjunction with the exhibition of the same name, shown at MoMA PS1, New York, from November 3, 2019 until March 1, 2020. Unfortunately, I was not able to visit the exhibition at the time.

${ }^{31}$ Peter Eleey and Ruba Katrib, "Preface and Acknowledgements," in Theater of Operations: The Gulf Wars 1991-2011, ed. Peter Eleey and Ruba Katrib (New York: MoMA PS1, 2019), 10.
} 


\section{National Oil Ceremonial Revisited}

In addition, the Kuwaiti government employed state ceremonies and national symbols to subsequently integrate the experiences into official narratives. By doing so, it aimed at performing and displaying stability and continuity, and guiding an official way of reading the historic event. Moreover, these symbolic forms can be interpreted as an attempt to level out the negative upheavals of petro-modernity by showing the government in a position of control, even if it is control over ceremonial and performative forms.

Historically, the first state official oil ceremony took place on June 30, 1946. That day, then-ruling Shaykh Ahmad al-Jaber Al Sabah inaugurated the first oil shipment to Britain, officially marking Kuwait's initiation as an oil-exporting country. Now-iconic photographs show the ruler turning a silver valve to open the pipes that would fill the oil tanker

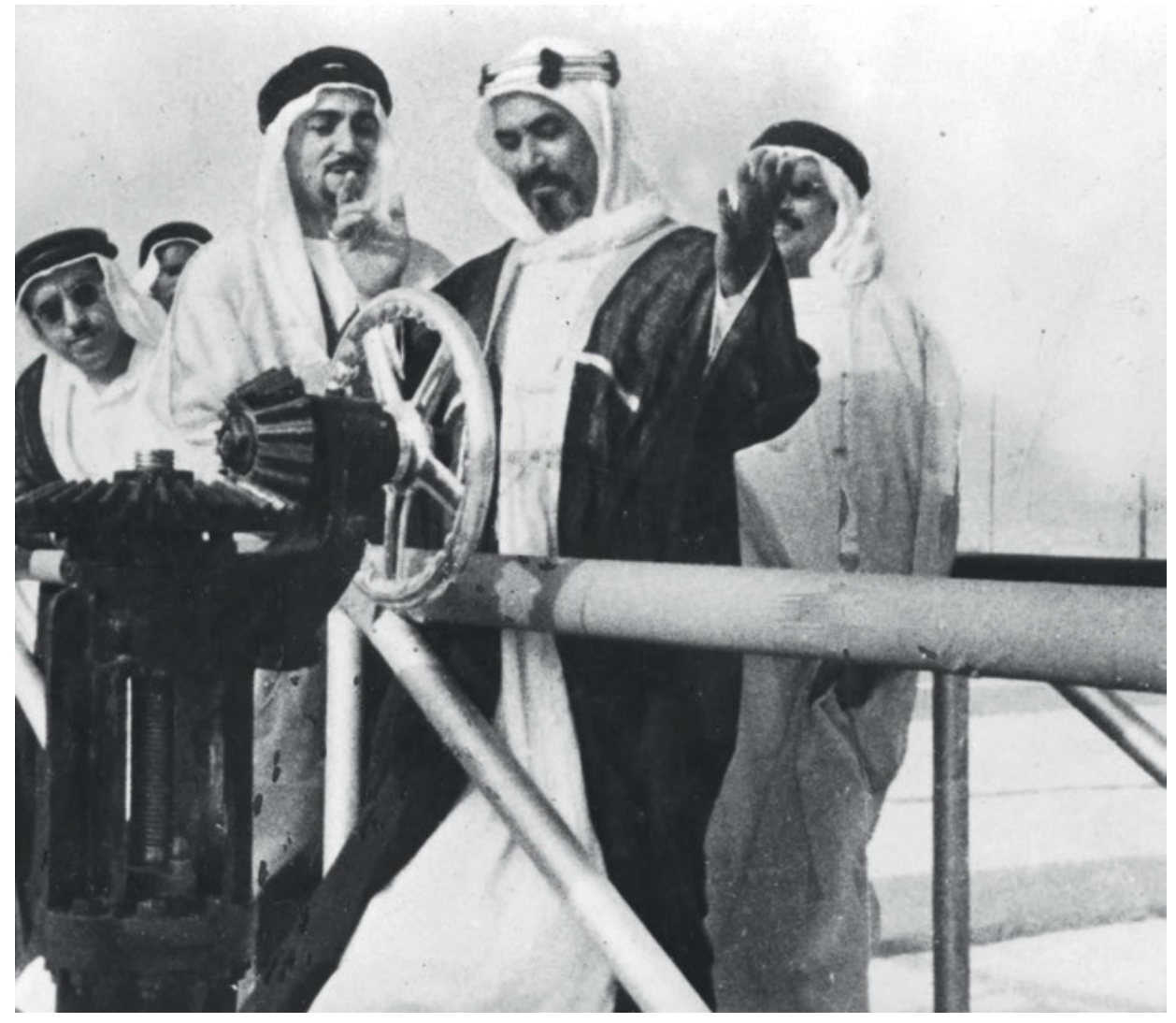

6.5 Black-and-white photograph of His Highness Shaykh Jabir Al Sabah at the ceremony to celebrate the first loading of oil in Kuwait. June 30, 1946, photographer unknown. 


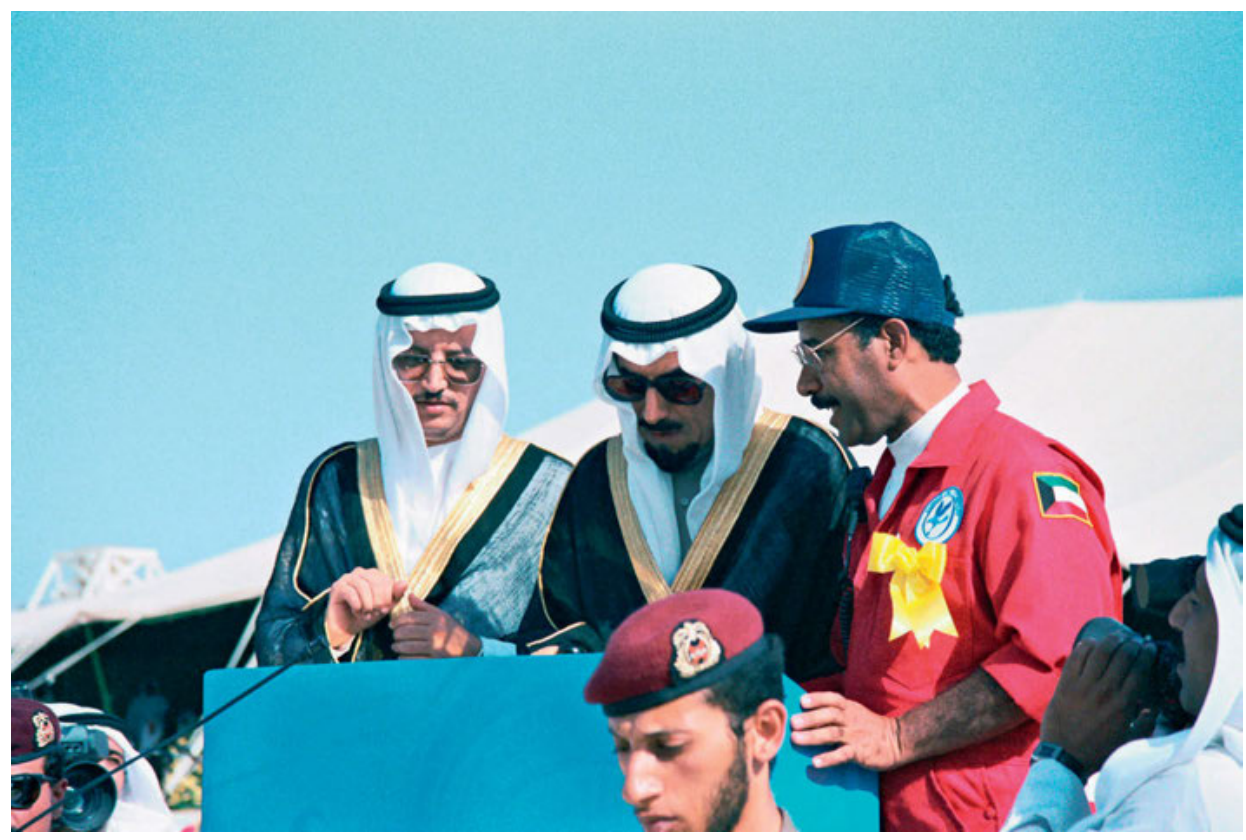

6.6 Emir Jaber al-Ahmad al-Jaber Al Sabah during the ceremony of extinguishing the last burning oil well, November 6, 1991.

British Fusilier with petroleum in less than twelve hours (fig. 6.5). ${ }^{32}$ In the photographs documenting the ceremonial setup, Shaykh Ahmad takes center stage together with the valve allegedly made from silver, arguably to symbolize petroleum's financial value. Today, this photo marks the beginning of Kuwait's oil industrialization. ${ }^{33}$

While the 1946 celebrations had signaled an official opening, the related 1991 event served to symbolize closure. On November 6, 1991, Emir Jaber al-Ahmad Al Sabah (r. 1977-2006) officially closed the last burning oil well, Burgan 118. Actually, firefighters had already quenched this well some days prior, but it was reignited to turn its capping into a symbolic event by the hand of the emir. This event also took place in the desert, where a stage had been erected, embedded into a landscape of large carpets, tents, and rows of chairs for the members of the royal family, government officials, the press, and the

${ }^{32}$ On the 1946 photograph and the iconography and (in)visibility of oil and water in the second half of twentieth-century Kuwait, see Hindelang, "Precious Property."

${ }_{33}$ This ceremony was repeated, almost reenacted, on June 30, 1996, in celebration of the oil industrialization's fiftieth anniversary. Again, Emir Jaber turned a golden valve in acknowledgment of the historic opening ceremony. The photographic documentation shows the emir, the valve, and several officials accompanying the ruler. Wearing a traditional bisht dhahabī, their clothing matched the valve, whose materiality had shifted from silver to gold, probably not only to highlight the value of the "black gold" but also the successful longevity of the industry. 
6.7 Two stamps from a set of four multicolor commemorative stamps issued on the occassion of the "First Anniversary of Extinguishing of Oil Well Fires," November 16, 1992.
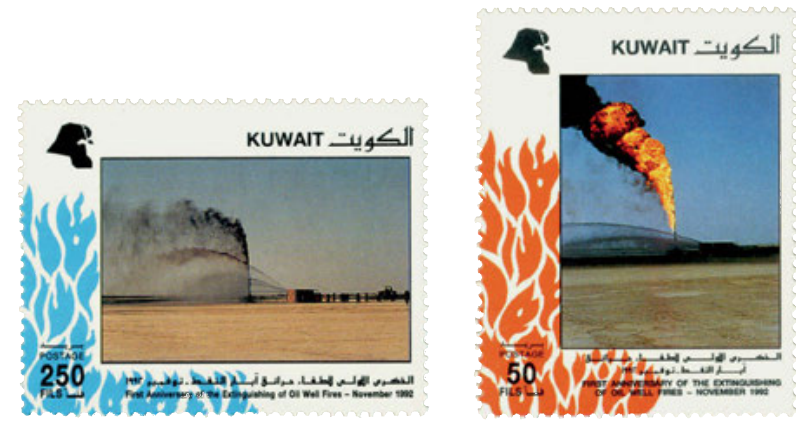

firefighter teams. Standing slightly elevated on a blue platform, the ruler used a remote electronic device to push the button that closed the well instead of turning a silver valve (fig. 6.6). Both the 1946 and the 1991 ceremony are decisive, orchestrated moments of national petroleum choreography that bind the state and the infrastructural flows of petroleum together in a lasting union. One year later, a commemorative Kuwaiti series was issued on the occasion of the first anniversary of extinguishing the invasion's oil well fires (fig. 6.7), honoring petroleum's long-standing relationship with stamp culture. ${ }^{34}$ It is striking that these three stamps mark one of the rare occasions that oil was visualized as a material substance and-in the form of a gusher-as a natural phenomenon on a Kuwaiti stamp.

Subsequently, Operation Desert Storm and the quenching of the oil spills and fires have become officially remembered and celebrated as "liberation." In 2011, the state of Kuwait celebrated a fifty/twenty anniversary: fifty years of independence and twenty years of liberation. Despite being framed as a national achievement and although Kuwaitis were important in organizing resistance inside and outside of the country during the Gulf War, the "liberation" was successful thanks to the US-led allied forces, as Kuwaiti curator and artist Barrak Alzaid analyzing the 2011 festivities in the magazine Ibraaz emphasized: "This spectacle, replete with images that manipulate nostalgia and assert a particular narrative of the Gulf War, ends in a reclamation of the country by and for the people." ${ }^{35}$ He attests "society's alienation from its legacy of war," for which the national celebrations are intended to provide "an identity that could be consumed and interpellated as the legitimate Kuwait." ${ }^{36}$ Alzaid thus analyzed the experience of the Gulf War, the vulnerability and the violence experienced as a lasting social trauma for the country that has not been fully overcome.

\footnotetext{
${ }^{34}$ Kuwait 1992, commem., MiNos. 1333-36.

${ }^{35}$ Barrak Alzaid, "Staging the Nation," Ibraaz, May 6, 2016, accessed July 8, 2020, https://www.ibraaz.org/ essays/149.

${ }^{36}$ Ibid.
} 
Ever since the Gulf War, the petroleum promise's iridescent spell on the region has begun to lift and petroleum's stranglehold on the future imaginary has begun to dwindle. The experience of a second rupture-caused by the Iraqi invasion, the oil spills, and Operation Desert Shield, as well as the subsequent loss of control over oil production and revenues-has created long-lasting effects. Some have come to see the first rupture-the rapid transformation from the pre-oil to the oil period-in a more subtle, at times even nostalgic light. Today, a growing awareness of climate change, the towering finitude of conventional oil, the sharply declined demand during COVID-19 lockdowns as well as the expansion of authoritarian control by national governments has led many in the Gulf to feel that past, present, and future no longer form a straight and fairly unobstructed path. There is a feeling that past and present do not align, and in fact may have never aligned, at least not in the way in which official narratives have suggested. As a result, doubt has proliferated: doubt about the state's image, but also doubt about the images that have typically showcased the oil period and Kuwait as petropolis. Today, contemporary art provides for a crucial arena where Kuwait's and the Gulf's mid-twentieth century oil history as well as the legacy of its urban visual culture can be critically investigated. 